\title{
THE EFFECT OF INTERNAL AND EXTERNAL FACTORS ON INCOME AND THE SUSTAINABILITY OF GROCERY STORE BUSINESS IN UBUD DISTRICT OF GIANYAR REGENCY, INDONESIA
}

\author{
Mardiana I Wayan*, Marhaeni A.A. I N. \\ Faculty of Economics and Business, University of Udayana, Indonesia \\ *E-mail: yanmardiana95@gmail.com
}

\begin{abstract}
Competition in traditional markets such as grocery stores with modern stores is currently considered unbalanced, causing the marginalization of small traders. This causes the grocery store to decline more and more. One of the reasons is the rapidly growing minimarket in Bali Province. The growing rapidly of minimarkets will certainly threaten the sustainability of the grocery store business in the vicinity. Based on this, the objectives of this study are 1 . To analyze the effect of internal factors and external factors on grocery store revenue; 2 . To analyze the effect of internal factors, external factors and income of the grocery store on the sustainability of the grocery store business; 3 . To analyze the indirect effect of internal factors and external factors on the sustainability of the grocery store business through the income of the grocery store. This research uses descriptive analysis tools and Structural Equation Model (SEM) with PLS (Partial Least Square). The data used are primary data and secondary data. Data collection used observation methods, structured interviews and in-depth interviews. Respondents in this study were grocery store entrepreneurs in Ubud District, Gianyar Regency, which were taken by quota sampling as many as 120 samples, which were selected by accidental sampling. The result of this research is that the grocery store internal factor variable has a positive and significant effect on the grocery store's income. The grocery store's external factor variable has no effect on the grocery store's income. The variable of the external factor of the grocery store and the variable of the income of the grocery store have a positive and significant effect on the sustainability of the grocery store business. The grocery store internal factor variable has no positive and significant effect on the sustainability of the grocery store business. There is an indirect effect of the grocery store internal factor variable on the sustainability of the grocery store business through the income of the grocery store is significant. There is no indirect effect of the grocery store external factor variable on the sustainability of the grocery store business through the income of the grocery store.
\end{abstract}

\section{KEY WORDS}

Grocery store, minimarket, business sustainability, internal factors, external factors.

The Central Bureau of Statistics Indonesia (2018) explains that a grocery store is a place of business in a permanent building that sells goods for daily needs and also sells food in retail. The grocery store does not have a self-service system, and even this grocery store is managed by one seller. A grocery store is a business that is owned by some people and is used as a support for their life. In addition the grocery store is easy in terms of establishment with a small capital; this business also has the potential to generate profits directly. Grocery store in general is family businesses have the possibility to also absorb labor. The grocery store itself is very close to the community, because its very easy establishment does not require large capital and uses a place that is not too wide. The grocery store itself has several advantages that make it popular with the community, such as the price is negotiable, and also provides goods that reflect local commodities in the area.

Competition of local capitalists (traditional markets such as grocery stores) with global capitalists (modern shops) is currently considered unbalanced, causing the marginalization of small traders as independent entrepreneurs in the global economy (Wijayati, 2013). Martin (2017) also explained that the times and changes in lifestyle that were promoted by various 
media as well as the establishment of a modern market had made a big impact on traditional markets, and the existence of traditional markets was slightly disturbed because many consumers prefer shopping in modern markets. Likewise, market changes force grocery stores to really understand and define competitive strategies for long-term business (Ahmad et al, 2014).

Table 1 - Number of Villages by Existence of Minimarkets and Grocery Stores in Bali Province in 2011, 2014 and 2018

\begin{tabular}{|c|c|c|c|c|c|c|c|c|c|c|c|}
\hline \multirow[b]{2}{*}{ Number } & \multirow[b]{2}{*}{$\begin{array}{c}\text { Regency/C } \\
\text { ity }\end{array}$} & \multicolumn{2}{|c|}{2011} & \multicolumn{2}{|c|}{2014} & \multicolumn{2}{|c|}{2018} & \multicolumn{2}{|c|}{$\begin{array}{c}\text { Growth } \\
2011-2014\end{array}$} & \multicolumn{2}{|c|}{$\begin{array}{c}\text { Growth } \\
2014-2018\end{array}$} \\
\hline & & \begin{tabular}{|c|} 
The \\
Grocery \\
Store
\end{tabular} & $\begin{array}{c}\text { Mini- } \\
\text { market }\end{array}$ & $\begin{array}{c}\text { The } \\
\text { Grocery } \\
\text { Store }\end{array}$ & $\begin{array}{l}\text { Mini- } \\
\text { market }\end{array}$ & $\begin{array}{c}\text { The } \\
\text { Grocery } \\
\text { Store }\end{array}$ & $\begin{array}{c}\text { Mini- } \\
\text { market }\end{array}$ & $\begin{array}{c}\text { The } \\
\text { Grocery } \\
\text { Store } \\
(\%)\end{array}$ & $\begin{array}{c}\text { Mini- } \\
\text { market } \\
(\%)\end{array}$ & $\begin{array}{c}\text { The } \\
\text { Grocery } \\
\text { Store } \\
(\%)\end{array}$ & $\begin{array}{l}\text { Mini- } \\
\text { market } \\
(\%)\end{array}$ \\
\hline 1 & Jembrana & 50 & 18 & 44 & 15 & 51 & 28 & $-4,17$ & $-5,90$ & 0,28 & 6,52 \\
\hline 2 & Tabanan & 129 & 42 & 133 & 49 & 133 & 59 & 1,02 & 5,27 & 0,00 & 4,98 \\
\hline 3 & Badung & 62 & 46 & 62 & 48 & 62 & 52 & 0,00 & 1,43 & 0,00 & 1,77 \\
\hline 4 & Giany ar & 69 & 38 & 70 & 44 & 70 & 55 & 0,48 & 5,01 & 0,00 & 5,42 \\
\hline 5 & Klungkung & 59 & 9 & 59 & 16 & 59 & 21 & 0,00 & 21,14 & 0,00 & 12,87 \\
\hline 6 & Bangli & 59 & 12 & 66 & 17 & 72 & 22 & 3,81 & 12,31 & 2,20 & 9,05 \\
\hline 7 & Karangasem & 76 & 17 & 78 & 28 & 78 & 35 & 0,87 & 18,10 & 0,00 & 10,87 \\
\hline 8 & Buleleng & 145 & 30 & 148 & 51 & 148 & 77 & 0,68 & 19,35 & 0,00 & 14,41 \\
\hline 9 & Denpasar & 43 & 39 & 43 & 42 & 43 & 43 & 0,00 & 2,50 & 0,00 & 1,40 \\
\hline \multicolumn{2}{|c|}{ Total Bali Province } & 692 & 251 & 703 & 310 & 716 & 392 & $\mathbf{0 , 5 3}$ & 7,29 & 0,46 & 6,58 \\
\hline
\end{tabular}

Source: The Central Bureau of Statistics Bali Province, 2018

This causes the grocery store to decline more and more. The decline in the development of grocery stores itself can be seen in Table 1, where it is explained that in Bali Province the number of villages according to the presence of grocery stores in 2011 was 692 villages, in 2014 there were 703 villages with a growth of 0.53 percent. The development of grocery stores from 2011 to 2018 only grew by 24 villages to 716 villages that have grocery stores with a growth of 0.46 percent during the 7 -year period. The development of the grocery store which is not so big indicates that the development of the grocery store itself is not so good in developing its business in the community.

One of the causes of the business development of grocery stores is not good in the presence because of the competitors from grocery stores, such as a minimarkets which are growing rapidly in Bali Province. In Table 1 it can be seen that in 2011 minimarkets had penetrated 251 villages and in 2014 minimarkets had penetrated 310 villages in Bali Province with a growth rate of 7.29 percent in the 3 years period. The development of minimarkets for 7 years from 2011 to 2018 was very rapid, even reaching 392 villages in Bali Province, with a growth rate of 6.58 percent. In addition to the large growth rate of minimarkets, their growth is also very fast compared to grocery stores business development. The vast difference between the developments between grocery stores and minimarkets reflects the difference in terms of the existence of the grocery store itself compared to the existence of minimarkets in business competition. Kumar et al. (2016) in his research which concluded that the majority of customers visit organized retail stores such as minimarkets for convenience and availability of various products. Makhitha et al. (2019) in his research also gives results that consumers shop at minimarkets based on five factors, namely personnel, convenience, product, service and price.

Many grocery store entrepreneurs have to start looking for alternatives how to overcome the competition that occurs between traditional businesses and modern businesses (Bakhri, 2017). Minimarkets with very fast growth and most of them do not even have a permit like in Gianyar Regency. Especially in Ubud District, where the number of minimarkets greatly exceeds the quota that has been set compared to other subdistricts in 
Gianyar Regency. This causes grocery stores, especially in Ubud District, must have a strategy to be able to develop and maintain their business sustainability. In addition to this, other problems from the rapid development of minimarkets cause grocery stores is required to be able to develop their business according to the development of the business world. As stated by Leonnard (2017) that the increasing number of modern retail stores in Indonesia is a challenge for every groceys store to maintain their business and increase the number of consumers. This makes the authors interested in conducting research on the influence of internal and external factors on the income and business continuity of grocery stores in Ubud District, Gianyar Regency.

The purposes of this study: 1) analyze the effect of internal factors and external factors on the income of grocery stores in Ubud District, Gianyar Regency, 2) analyze the effect of internal factors and external factors as well as grocery store income on the sustainability of the grocery store business in Ubud District, Gianyar Regency, and 3 ) To analyze the indirect effect of internal factors and external factors on the sustainability of the grocery store business through the income of grocery stores in Ubud District, Gianyar Regency.

\section{LITERATURE REVIEW}

J.H. Boeke the Dutch economist was a pioneer who developed the theory of dualism. Boeke uses the term dualistic society for a society that exhibits distinct characteristics in the midst of a synchronous and mature social system where historical evaluations of homogeneous societies are usually separated from each other through transitional forms such as between pre-capitalism and full capitalism through early capitalism. Such a dualistic society is characterized by the existence of a more advanced imported Western system and an indigenous pre-capitalist agricultural system.

In addition to the dualism of society, Boeke also explained about the dualism of technology. Technological dualism means the use of various production functions in the developed sector and the traditional sector in the underdeveloped economy. The existence of such dualism exacerbates the problem of technological unemployment or structural unemployment in the industrial sector and hidden unemployment in the rural sector. The dualism theory in this study will be used to describe the differences between grocery stores and modern stores (Jhingan, 2014: 201).

The first theory regarding retail location comes from microeconomics, with a focus on spatial aspects of competition. A well-known model is the principle of minimum differentiation by Hotelling (1929) in Wieland (2018), describing a duopoly with two companies selling the same goods at the same selling price in a linear market. Both consumers and sellers have perfect market information. Customers are distributed evenly and must pay the selling price of goods and transportation costs to reach the seller. Since the latter is different between all consumers, they face different prices.

As assumed by location theory and discussed in the context of local supply, the most important influence on store choice is the spatial accessibility of stores, no matter how they are operated. This does not mean choosing the nearest store but in the consumer trade-off, accessibility has the highest weight. While store size has a clear positive impact, no clear results on chain pricing policies can be found. There is also empirical evidence of a positive agglomeration effect with respect to clustering different store formats (Wieland, 2018).

Game theory is one of the tools used by economists to study the choice of strategies taken by companies. Game theory itself explains more about price behavior and market entry behavior in imperfect competition markets. Game theory tries to describe strategies for complex situations in a very simple way. Any situation in which individuals have to make strategic choices and the end result depends on the actions each person chooses can be viewed as a game. All games have three basic elements namely players, strategy and rewards. Players are actors or individuals who make decisions. Actions that are open to a player are called strategies. And the final result for players from a game as a conclusion is called a reward (Nicholson, 2002: 386). 
Game theory is used in this study which relates to indicators of the affordability of goods prices. The price of goods sold by the grocery store should be affordable by consumers and certainly not higher than the prices given by competitors in the vicinity such as minimarkets. In game theory which explains the Bertrand balance which is a pricing strategy in which an individual or company both sets the same price because they share the same market share, thus achieving a balance called Bertrand equilibrium (Nicholson, 2002: 399).

Listihana and Aquino (2014) explain operating income is all outputs generated from a certain activity, in practice, seeking certain jobs using various methods, thus the business results obtained are also the total of all the outputs produced. In this study, the income approach will be used to calculate the size of the income of grocery store business. Grocery store revenue will be calculated from the total sales received by the grocery store entrepreneur to find out the amount of income he gets in a certain period. Mankiw et al. (2014: 270) explains that the profit is the total income of a company reduced its total costs, where it is explained that total revenue is the amount of money received by the company from selling its products and total cost is the market value of the ingredients used by the company in the production process. Pertiwi, et al (2016) explain that prices have many forms and carry out many functions and consist of many components. Price is a value expressed in currency for exchange/transaction or an amount of money that must be paid by consumers to obtain goods and services. Price is the amount of money that customers have to pay to get the product.

Supriyanto (2018) explains that place means where the place/location is intended, how is the distribution channel, how many channels, and the condition of the distributors needed. Utami (2018) explains that the location of the business will determine how easy it is for consumers to reach the business location to buy a product. The more strategic the location of the grocery store business, the easier it will be for consumers to reach it. Business locations that are too far away and difficult to reach by consumers will reduce the intention of consumers to shop at the grocery store.

According to the Presidential Regulation of the Republic of Indonesia Number 112 of 2007 concerning the Arrangement and Development of Traditional Markets, Shopping Centers and Modern Stores, a market is an area where goods are bought and sold with more than one seller, either called a shopping center, traditional market, shops, malls, plaza, trade center or other designations. The main characteristics of modern stores are management that is carried out in a modern way using technology, prices are non-negotiable, the facilities provided are sophisticated, there are several payment methods that can be used, such as a credit cards, debit cards or e-money, using the principle of self-service, there are more promotion, discounts and prizes are generally managed by the private sector and the condition of the building or building is clean and well-maintained (Yulita et al., 2019).

A grocery store is one form of traditional market that is often found and even exists in every rural/city area. This grocery store sells various kinds of goods in the form of daily necessities, where the sales system still uses the traditional system, unlike modern stores that already use various technologies to serve consumers. The types of goods sold in this grocery store are relatively few compared to modern stores with the smallest scale like a minimarkets. The grocery store is a private business that depends on capital from the owner himself (Hadisiwi and Rakhman, 2014). Mas et al. (2014) in his research mentions that there is a difference between modern markets and traditional markets, namely based on his observations of observing traders in traditional markets who serve every customer with charm, conversations about social issues, hot news, while customers choose the goods to be purchased. It is different from modern store that just say hello, with consumers who pick up the goods to be purchased, take them to the cashier, then pay and finish.

\section{CONCEPTUAL FRAMEWORK}

The grocery store itself, with the trend of minimarket growth, has resulted in a decrease in the competitiveness of grocery stores. The decline in the competitiveness of the grocery 
store has resulted in the sustainability of the grocery store business being increasingly threatened, and of course it will greatly affect the welfare of the grocery store entrepreneurs. Dey et al. (2012) in his research explained that the retail business is one of the fastest growing industries in India over the last few years. Jumaidi et al. (2019) in his research, the results showed that the negative perception of retail business actors' grocery stores towards the existence of minimarkets was included in the high category. The existence of minimarkets for grocery stores has a negative impact on turnover, income and the number of customers. The implementation of government regulations regarding minimarkets has not been running properly. Judging from the efforts made by grocery stores business actors to maintain their business existence, they are very minimal.

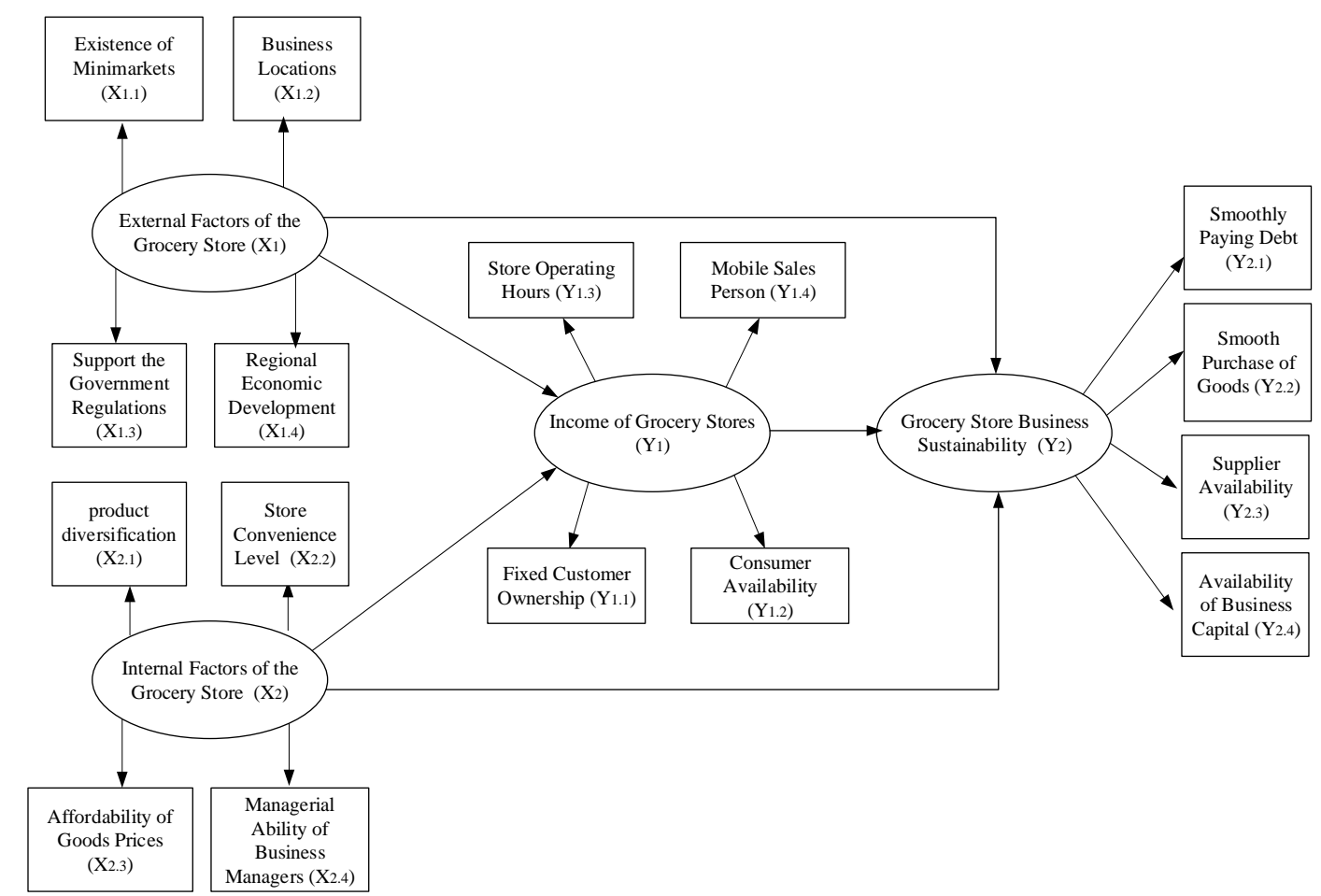

Figure 1 - Conceptual Framework the Effect of Internal and Eksternal Factors on Income and the Sustainability of Grocery Store Business in Ubud District Gianyar Regency

Nesset et al. (2021) stated that choosing a strategic store location can be used to develop a sustainable business and have a competitive advantage, therefore the location of the store is very important for any retailer to maintain its business continuity. Customer perception of store location is also believed to affect customer satisfaction and store positive image. Nelwan et al. (2017) explained that traditional markets must provide strategies in dealing with modern markets because modern markets exist more than traditional markets. A strategy is needed from traders to retain customers and the existence of their business to develop a distinctive and characteristic store image that can meet consumer needs and demands as is done by modern markets.

Ayu et al. (2016) who examined the analysis of the resilience factor of grocery stores against minimarket competitors in Badung Regency. The results of his research indicate that external factors (strategic business location, competitiveness, presence of minimarkets) have a positive and significant effect on the income of grocery stores. Meanwhile, internal factors (price of goods, mobile labor, adequate business capital, product diversification) also have a positive and significant effect on the income of grocery stores traders. Indirectly, internal factors and external factors affect the endurance of grocery stores in Badung Regency through the income of grocery stores. Based on the explanation, it can be concluded that the conceptual framework of this research is shown in Figure 1. 
Based on the description above, the hypotheses in this study are as follows: 1) Internal factors (product diversification, store convenience level, affordability of goods prices and managerial ability of business managers) and external factors (existence of minimarkets, business locations, support the government regulations and regional economic development) grocery stores have a positive effect on the income of grocery stores in Ubud District, Gianyar Regency. 2) Internal factors (product diversification, store convenience level, affordability of goods prices and managerial ability of business managers) and external factors (existence of minimarkets, business locations, support for government regulations and regional economic development) and income of grocery stores have a positive effect on grocery store business sustainability in Ubud District, Gianyar Regency. 3) Internal factors (product diversification, store convenience level, affordability of goods prices and managerial ability of business managers) and external factors (existence of minimarkets, business locations, support for government regulations and regional economic development) grocery stores have an indirect effect on the sustainability of the store grocery business stores through the income of grocery stores in Ubud District, Gianyar Regency.

\section{METHODS OF RESEARCH}

The research design used in this study is a quantitative research design and measurements are using quantitative data. The main data used in this study is primary data from this study obtained from respondents, namely grocery stores entrepreneurs. To obtain primary data, a structured interview method was used using a questionnaire to the respondents. Secondary data is also used in this study obtained from the Central Bureau of Statistics of Gianyar Regency and Bali Province, the Gianyar Regency Industry and Trade Office and the Bali Province Industry and Trade Office. Sampling was use by quota sampling, due to the unavailability of the population of grocery store entrepreneurs in Ubud District, Gianyar Regency. The number of samples taken was 15 samples in each village in Ubud District, Gianyar Regency, which were taken by accidental sampling. The number of villages in Ubud district of Gianyar Regency is 8 villages, so that the total sample obtained is 120 samples.

Table 2 - Convergent Validity Test Results

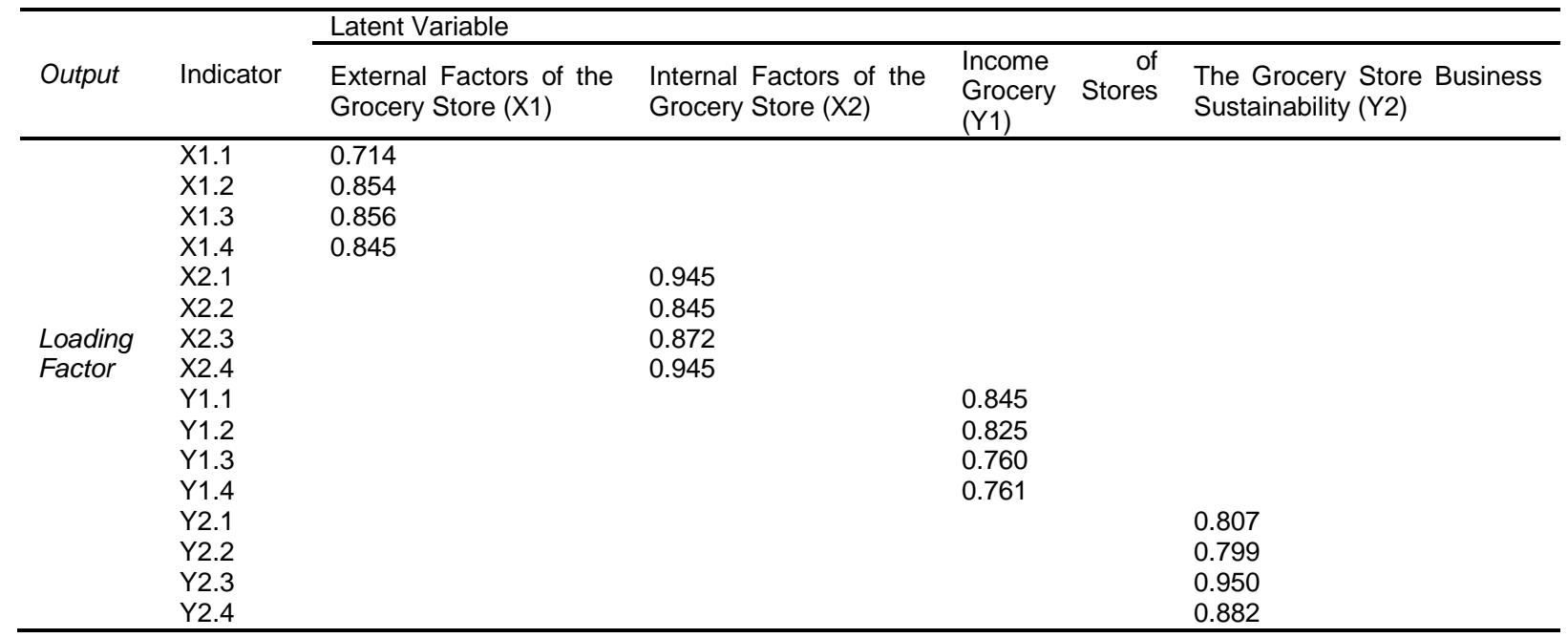

Source: Primary data processed, 2021.

The data that has been obtained were analyzed using descriptive analysis and Structural Equation Model (SEM) with an alternative PLS (Partial Least Square) to determine the influence of internal factors and external factors on the income and sustainability of the grocery store business in Ubud District, Gianyar Regency. The equation model in this study is as follows: 


$$
\begin{aligned}
& Y_{1}=a_{1}+\beta_{1} X_{1}+\beta_{2} X_{2}+e_{1} \\
& Y_{2}=a_{2}+\beta_{3} X_{1}+\beta_{4} X_{2}+\beta_{5} Y_{1}+e_{2}
\end{aligned}
$$

Where: $X_{1}=$ External Factors of the Grocery Store; $X_{2}=$ Internal Factors of the Grocery Store $Y_{1}=$ Income of Grocery Stores; $Y_{2}=$ The Grocery Store Business Sustainability; $\beta_{1-2-3-4-5}=$ The coefficient of regression is showing the variation in the dependent variable as due to changes in the independent variables; $e_{1}, e_{2}=$ error; $a_{1}, a_{2}=$ constant.

Table 3 - The Values of Cronbach's Alpha, Composite Reliability and AVE

\begin{tabular}{llll}
\hline Variable & Cronbach's Alpha & Composite Reliability & AVE \\
\hline External Factors of the Grocery Store (X1) & 0.839 & 0.890 & 0.671 \\
Internal Factors of the Grocery Store (X2) & 0.924 & 0.946 & 0.815 \\
Income of Grocery Stores (Y1) & 0.810 & 0.875 & 0.638 \\
The Grocery Store Business Sustainability (Y2) & 0.883 & 0.920 & 0.743 \\
\hline
\end{tabular}

Source: Primary data processed, 2021.

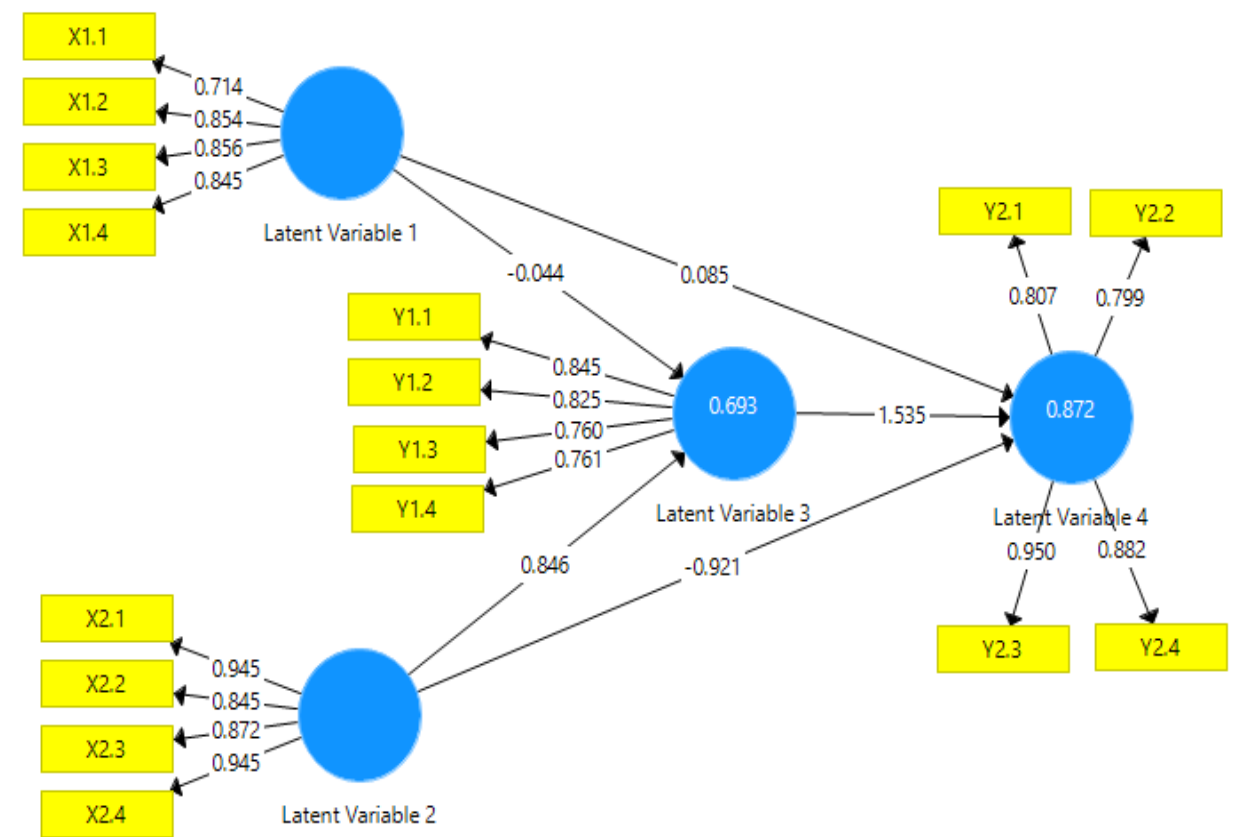

Figure 2 - Path Coefficient of Effect of Internal and External Factors on Income and the Sustainability of Grocery Store Business in Ubud District Gianyar Regency

\section{RESULTS AND DISCUSSION}

The convergent validity of the measurement model that has reflective indicators can be assessed from the loading factor (the correlation between item score/component score and construct score) the indicators that measure the construct. An indicator can be declared valid if it has a loading factor above 0.7 to the intended construct. Based on Table 2 it can be seen that all loading factor indicators have values greater than 0.7 . This shows that the conditions for convergent validity have been met. In Table 3 it can be seen that the Composite Reliability of each construct has a value greater than 0.70 . This means that all constructs have high internal consistency. In addition, a construct is also seen for its reliability through Cronbach's Alpha. Role of thumb Cronbach's Alpha or Composite Reliability value must be greater than 0.7. Judging from Table 3 which shows the Cronbach's Alpha value of each construct which is greater than 0.70 , it can be said that the measurer in this study is reliable.

Answer the research objectives influence internal factors and external factors on the income of a grocery store in Ubud District Gianyar Regency used SEM PLS analysis. The results of data analysis using the SEM PLS method showed that the external factor of the 
grocery store variable $\left(X_{1}\right)$ had no significant effect on the grocery store income $\left(Y_{1}\right)$ with a coefficient of -0.044 and a t-statistic of 0.675 (t-statistic <1.65), then the hypothesis is rejected, which means that the external factor of the grocery store variable $\left(X_{1}\right)$ has no significant effect on the income of the grocery store $\left(\mathrm{Y}_{1}\right)$. The internal factor of the grocery store $\left(X_{2}\right)$ has a positive and significant effect on the income of the grocery store $\left(Y_{1}\right)$ of 0.846 with $p$ value $=0.000$ and t-statistics of 31.347 (t-statistics $>1.65$ ), then the hypothesis is accepted, which means the internal factor of the grocery store $\left(X_{2}\right)$ has a positive effect on the income of the grocery store $\left(Y_{1}\right)$.

The results of this study are in accordance with the results of research from Masyhuri and Utomo (2017) which states that the existence of Alfamart and Indomaret does not cause a decline in Sleko traditional market activities in terms of buying and selling. The Sleko market still has consumers even though Alfamart and Indomaret are located near the market. External factor variables with indicators of the existence of minimarkets in Ubud District Gianyar Regency have no effect on the income of grocery stores in Ubud District Gianyar Regency. Otaibi and Kausar (2014) also stated the same thing where in their research it was revealed that in Saudi Arabia although there are very many shopping centers, consumers prefer to shop at special grocery stores to buy for groceries. Consumer loyalty is formed due to the quality of grocery store services that can satisfy consumers.

Based on this statement, the existence of minimarkets has no effect on the income of grocery stores in Ubud District, Gianyar Regency. This is because grocery stores have their own differences that make them different from the minimarkets, so that customers after the establishment of the minimarket will still buy at the grocery store because there is trust from consumers in the grocery store which makes them still shoping at the grocery store. Support for Government Regulations is also an important thing to note, because grocery store traders do not feel a direct touch from the regulations made by the government to increase their income (Jumaidi, 2019).

The existence of minimarkets does not have an effect on the income of grocery stores in Ubud District Gianyar Regency, but based on the dualistic theory proposed by Boeke in Jhingan, (2014: 201), there is a very striking difference between grocery stores and modern stores. One of them is the dualism in the use of technology between grocery stores and modern stores. Modern stores in their operational activities already use modern technology such as payment by scanning barcodes, product prices can be accessed online through supporting applications or social media, and various modern technologies that support their operations. Unlike the case with grocery stores, which in their operations, still use traditional methods. This very striking difference, of course, if not overcome by various attractions that highlight the advantages of the grocery store, then of course the grocery store business will not be able to run smoothly. Modernization also plays an important role for the development of grocery stores as in the study of Saha et al, (2019) which stated that modernization is one of the factors that determine consumer choice to shop for a retail business.

Table 4 - Path Coefficient

\begin{tabular}{|c|c|c|c|c|c|c|}
\hline Construct & $\begin{array}{l}\text { Original } \\
\text { Sample (O) }\end{array}$ & $\begin{array}{l}\text { Sample } \\
\text { Mean (M) }\end{array}$ & $\begin{array}{l}\text { Standard Deviation } \\
\text { (STDEV) }\end{array}$ & $\begin{array}{l}\text { T Statistics } \\
(|O / S T D E V|)\end{array}$ & $\begin{array}{l}P \\
\text { Values }\end{array}$ & Note \\
\hline $\mathrm{X}_{1} \rightarrow \mathrm{Y}_{1}$ & -0.044 & -0.033 & 0.065 & 0.675 & 0.500 & Not significant \\
\hline$X_{1} \rightarrow Y_{2}$ & 0.085 & 0.077 & 0.040 & 2.140 & 0.033 & $\begin{array}{l}\text { Positive \& } \\
\text { Significant }\end{array}$ \\
\hline$X_{2} \rightarrow Y_{1}$ & 0.846 & 0.848 & 0.027 & 31.347 & 0.000 & $\begin{array}{l}\text { Positive \& } \\
\text { Significant }\end{array}$ \\
\hline $\mathrm{X}_{2} \rightarrow \mathrm{Y}_{2}$ & -0.921 & -0.949 & 0.141 & 6.543 & 0.000 & $\begin{array}{l}\text { Negative and } \\
\text { Significant }\end{array}$ \\
\hline $\mathrm{Y}_{1} \rightarrow \mathrm{Y}_{2}$ & 1.535 & 1.556 & 0.095 & 16.150 & 0.000 & $\begin{array}{l}\text { Positive \& } \\
\text { Significant }\end{array}$ \\
\hline $\begin{array}{l}R \text { Square } \\
\mathrm{Y}_{1} \\
R \text { Square } \\
\mathrm{Y}_{2}\end{array}$ & $\begin{array}{l}0,693 \\
0,872\end{array}$ & & & & & \\
\hline
\end{tabular}

Source: Primary data processed, 2021 
Table 5 - The Value of Indirect Effects

\begin{tabular}{lllllll}
\hline Construct & $\begin{array}{l}\text { Original } \\
\text { Sample (O) }\end{array}$ & $\begin{array}{l}\text { Sample } \\
\text { Mean }(M)\end{array}$ & $\begin{array}{l}\text { Standard } \\
\text { Deviation } \\
\text { (STDEV) }\end{array}$ & $\begin{array}{l}\text { T Statistics } \\
(\mid \text { OSTDEV|) }\end{array}$ & $\begin{array}{l}P \\
\text { Values }\end{array}$ & Note \\
\hline $\mathrm{X}_{1} \rightarrow \mathrm{Y}_{1} \rightarrow \mathrm{Y}_{2}$ & -0.068 & -0.051 & 0.100 & 0.675 & 0.500 & $\begin{array}{l}\text { Not Significant } \\
\mathrm{X}_{2} \rightarrow \mathrm{Y}_{1} \rightarrow \mathrm{Y}_{2}\end{array}$ \\
\hline
\end{tabular}

Source: Primary data processed, 2021.

Note: $X_{1}=$ External Factors of the Grocery Store; $X_{2}=$ Internal Factors of the Grocery Store; $Y_{1}=$ Income of Grocery Stores; $Y_{2}=$ The Grocery Store Business Sustainability.

Based on the results of the study, internal factor of the Grocery Store variables consisting of indicators of product diversification, store convenience level, affordability of goods prices, managerial ability of business managers affect the income of the grocery store, if the grocery store further improves the internal factors of the grocery store, the income from the grocery store will increase. Product diversification is very important for grocery stores in increasing their income, of course because there are many competitors such as minimarkets around grocery stores. This product diversification is a distinctive feature of grocery stores, because they can provide products that cannot be provided by minimarkets. Wiputra et al, (2015) in their research stated that one of the things that can increase income is to increase the convenience of grocery stores, so that consumers feel comfortable shopping. Customers will see the overall appearance of a store before entering a store to find the product they want to buy. Attractive displays will provide customers with the first experience.

Answering the research objective of the influence of internal factors, external factors and grocery store income on the sustainability of the grocery store business in Ubud District Gianyar Regency, used SEM PLS analysis. The results of data analysis using the SEM PLS method showed that the grocery store external factor variable $\left(X_{1}\right)$ had a positive and significant effect on the sustainability of the grocery store business $\left(\mathrm{Y}_{2}\right)$ of 0.085 with $p$ value $=0.033$ and t-statistics of 2.140 (t-statistics $>1,65$ ), then the hypothesis is accepted which means that the external factor of the grocery store $\left(X_{1}\right)$ has a positive effect on the sustainability of the grocery store business $\left(Y_{2}\right)$. The grocery store internal factor variable $\left(\mathrm{X}_{2}\right)$ has a non-positive and significant effect on the sustainability of the grocery store business $\left(Y_{2}\right)$ of -0.921 with $p$ value $=0.000$ and t-statistics of 6.543 (t-statistics $>1.65$ ), then the hypothesis is rejected which means the internal factor of the grocery store $\left(X_{2}\right)$ has no positive effect on the sustainability of the grocery store business $\left(Y_{2}\right)$. The grocery store income variable $\left(Y_{1}\right)$ has a positive and significant effect on the sustainability of the grocery store business $\left(Y_{2}\right)$ of 1.535 with $p$ value $=0.000$ and t-statistics of 16.150 (t-statistics > 1.65), then the hypothesis is accepted which means grocery store income $\left(Y_{1}\right)$ has a positive effect on the sustainability of the grocery store business $\left(\mathrm{Y}_{2}\right)$.

Based on these results, it can be stated that if the external factors of the grocery store to be improved, the sustainability of the grocery store business will increase. As in the research of Hartomo and Malik (2013) if local government policies are relatively clear and directed, it will be a positive signal of local government interventions in business continuity in Surakarta City. The existence of minimarkets also has a positive influence on the sustainability of the grocery store business. Such as research from Muhzinat (2019) which concludes that the existence of minimarkets has an influence on grocery stores, namely it does not decrease the desire of grocery store entrepreneurs to remain able to compete with minimarkets. Support for government regulations also has an influence on the sustainability of the grocery store business. Hasbi (2016) in his research explains that the Magelang City government's efforts to overcome the increasing number of modern stores have issued a policy from the Mayor, namely by limiting the number of modern stores in Magelang City to only 20 outlets.

As assumed by location theory and discussed in the context of local supply, the most important influence on grocery store selection by consumers is the store's spatial accessibility, by selecting the nearest store, no matter how it operates (Wieland, 2018). The 
location of the business will certainly determine the sustainability of the grocery store business itself, especially grocery stores located around community settlements which allow consumers to choose to buy at grocery stores compared to shopping at modern stores. The strategic location of the business also makes the grocery store always have the possibility to maintain its business, as quoted from Wieland (2018) that the proximity of the grocery store to consumers will make it a special attraction for consumers to shop at the grocery store.

Based on these results, the grocery store internal factor variable has a negative and significant effect on the sustainability of the grocery store business. Based on these results, it can be stated that if the grocery store is improving the internal factors of the grocery store, the sustainability of the grocery store business will decrease. This is when grocery store entrepreneurs diversify products, then of course if there is not enough capital reserves to support the turnover of stocks product, it will threaten the sustainability of the grocery store business itself. Yuningrum (2016) in his research explains that grocery stores must improve service and cleanliness so that buyers feel comfortable buying. Because most of the respondents stated that the grocery store was not clean and the service was not friendly. Making improvements to the convenience of the grocery store also requires large capital from the grocery store entrepreneur, so that with a little capital the continuity of the grocery store business will certainly be threatened.

Based on these results, it can be stated that if the income of the grocery store increases, the sustainability of the grocery store business will increase. Yanti, et al (2018) explain that the level of business sustainability in general is in the high category on average in their research. Business actors pay more attention to increasing business profits. Because with increased income, it will certainly provide benefits that will maintain the sustainability of the grocery store business itself. Vanessa and Japutra (2017) state that knowing from customer profiles will help grocery store entrepreneurs to make improvements to the grocery store itself, for example in determining what products are most in demand by customers. Especially in Ubud District Gianyar Regency, where people who are very deep in Balinese culture will certainly really need ceremonial materials for traditional ceremonies, so that with information from customer profiles like that. The choice of products that will be sold by the grocery store would be better to provide ceremonial materials for the ceremony in Bali. Providing these products will certainly be a iterested for customers to shoping at the grocery store.

Answering the research objective of the indirect effect of internal factors and external factors on the sustainability of the grocery store business through the income of grocery stores in Ubud District Gianyar Regency, used SEM PLS analysis. The results of data analysis using the SEM PLS method showed that the indirect effect of the grocery store external factor variable $\left(X_{1}\right)$ on the sustainability of the grocery store business $\left(Y_{2}\right)$ through the grocery store income $\left(Y_{1}\right)$ obtained t-statistics $(0.675)<t$ table $(1.65)$, so that the grocery store income hypothesis $\left(Y_{1}\right)$ mediating the influence of the grocery store external factor $\left(X_{1}\right)$ on the business continuity of the grocery store $\left(Y_{2}\right)$ is rejected. The indirect effect of grocery store internal factor variables $\left(\mathrm{X}_{2}\right)$ on grocery store business continuity $\left(\mathrm{Y}_{2}\right)$ through grocery store income $\left(Y_{1}\right)$ obtained t-statistics (12.011) > t table (1.65), so the grocery store income hypothesis $\left(Y_{1}\right)$ mediating the influence of the grocery store internal factors $\left(X_{2}\right)$ on the business continuity of the grocery store $\left(\mathrm{Y}_{2}\right)$ is accepted.

Based on this reselut, external factors have no effect on the sustainability of the grocery store business through the income of the grocery store. Different things resulted from Nuraini's research (2018) indirectly external factors (strategic business location, competitive ability, presence of minimarkets) have a positive and significant impact on the resilience of traditional warung traders through the income of grocery stores. Based on the results of the research, internal factors affect the sustainability of the grocery store business through the income of the grocery store. The other of that Nuraini (2018) which shows too that indirectly, internal factors (product prices, number of workers, product diversification) directly have a positive and insignificant effect on the resilience of warung traders through the income of warung traders. 
Saber and Weber (2019) explain that a financial statement business is very basic for the sustainability of the business. The financial statements will describe how the business's finances are now and also in the future. Likewise with a grocery store which is a business, so ideally it has a financial report or on a small scale in the form of notes on the finances of the grocery store itself. Notes on the finances of the grocery store itself will describe the financial condition of the grocery store including how much profit or loss the grocery store earns. The notes to grocery store finances will also illustrate the separation between personal finances and grocery store business finances. This is necessary because most of the respondents who are entrepreneurs of grocery stores in Ubud District Gianyar Regency are private businesses and do not even have reports or records on the finances of the grocery store business.

The affordability of the price of goods is also an important thing as stated by Kumar, et al (2016) in their research which states that consumers tend to be interested in shopping for a retail business depending on the profits or price promotions they get. There is certainly not only one grocery store located in Ubud District Gianyar Regency; therefore the grocery store must be able to apply game theory in applying the price of the goods to be sold. The price of goods sold by the grocery store should be affordable by consumers and certainly not higher than the prices given by competitors in the vicinity such as minimarkets or the other grocery store. Grocery stores can collaborate with other grocery stores to make a price for products that is very affordable for consumers, so that consumers will be more interested in shopping at a grocery store.

\section{CONCLUSION}

The conclusion of this research is that the external factor variable of the grocery store has no significant effect on the income of the grocery store. The grocery store internal factor variable has a positive and significant effect on the grocery store's income. The variable of the external factor of the grocery store and the income of the grocery store has a positive and significant effect on the sustainability of the grocery store business. The grocery store internal factor variable has no positive and significant effect on the sustainability of the grocery store business.

The indirect effect of the grocery store external factor variable on the sustainability of the grocery store business through grocery store income is not significant. This means that the income of the grocery store does not mediate the influence of the external factors of the grocery store on the sustainability of the grocery store business. The indirect effect of grocery store internal factor variables on grocery store business continuity through grocery store revenue is significant, which means grocery store revenue mediates the influence of grocery store internal factors on grocery store business continuity.

\section{SUGGESTIONS}

Suggestions that can be given based on the results of the study are grocery stores need to make improvements to business management, especially to financial records so that with simple financial records it can be planned to return products purchases. In addition to these simple financial records, it can be seen how much profit and loss you get and can separate the store business finances and the grocery store family's personal finances. The grocery store also needs to make improvements to the appearance of the products arrangement and maintain the cleanliness of the grocery store, so that it becomes the initial interested for consumers to make purchases at the grocery store. In addition, grocery stores are expected to provide delivery services for consumers, especially for purchasing consumers needs in the morning, so that it becomes make consumers interested to continue shopping at the grocery store. Grocery stores are also expected to be able to provide products needed by local communities such as ritual materials for traditional ceremonies in Bali, there by providing product diversification for competitors, especially minimarkets. 
The government is expected to provide special capital assistance for grocery store entrepreneurs, because grocery store entrepreneurs are businesses owned by individuals that can absorb labor. The capital provided must not only provide capital, but the need for assistance by the Government so that the capital provided can increase the business capacity of the grocery store. The government is also expected to provide access to information or central suppliers to purchase merchandise so that the prices obtained can be cheaper.

\section{REFERENCES}

1. Ahmad, Fauziah Sh., Ihtiyar, Ali \& Omar, Rosmini. 2014. A Comparative Study on Service Quality in the Grocery Retailing: Evidence from Malaysia and Turkey. ProcediaSocial and Behavioral Sciences, 109, pp: 763 - 767.

2. Ayu, I Gusti Agung Rai Yudhi Astiti, Sudibia, I Ketut \& Djayastra, I Ketut 2016. Analisis Faktor Ketahanan Pedagang Warung Tradisional Menghadapi Pesaing Minimaret di Kabupaten Badung. Jurnal Buletin Studi Ekonomi, 21 (2), pp: 172 - 180.

3. Badan Pusat Statistik Kabupaten Gianyar. 2020. Kabupaten Gianyar dalam Angka 2020. Badan Pusat Statistik Kabupaten Gianyar: Gianyar.

4. Badan Pusat Statistik Provinsi Bali. 2020. Provinsi Bali dalam Angka 2020. Badan Pusat Statistik Provinsi Bali: Denpasar.

5. Badan Standarisasi Nasional. 2018. Belajar dari Kabupaten Gianyar Atasi Serbuan Minimarket. [Online] diakses dari: https://bsn.go.id/main/berita/detail/9027/belajar-darikabupaten-gianyar-atasi-serbuan-minimarket [Diakses pada 26 Pebruari 2021].

6. Bakhri, Syaeful. 2017. Strategy for Increasing Traditional Market Competitiveness in Dealing with the Presence of Modern Market. Journal of Ek-Regional, 12 (1), pp: $9-17$.

7. Bali Antaranews. 2018. Minimarket di Gianyar Lebihi Kuota. [Online] diakses dari: https://bali.antaranews.com/berita/124979/minimarket-di-gianyar-lebihi-kuota [Diakses pada 26 Pebruari 2021].

8. Dey, Surajit, Rafat, Sameena \& Sageer, Alam. 2012. Retailers and Customers: Problems and Perspectives. IOSR Journal of Business and Management, 5 (6), pp: $45-53$.

9. Ghozali, Imam. 2014. Structural Equation Modeling. Metode Alternatif dengan Partial Least Square (PLS). Edisi 4. Semaran: Badan Penerbit Universitas Diponogoro.

10. Hadisiwi, Purwanti \& Rakhman, M. Kh.. 2014. Kualitas Jasa Pelayanan Warung Tradisional di Tengah Persaingan Global. Jurnal Kajian Komunikasi, 2 (2), pp: 118 - 125.

11. Hartomo, Deny Dwi dan Cahyadin, Malik. 2013. Pemeringkatan Faktor Keberlangsungan Usaha Industri Kreatif di Kota Surakarta. Jurnal Ekonomi dan Kebijakan Publik, 4 (2), pp: $225-236$.

12. Hasbi, Ghassan Niko, Adhisyah, Siti Vickie Dina Maulaya dan Irmawan, Achmat. 2016. Analisis perizinan Pendirian Alfamart dan Dampak Negatif Terhadap Perusahaan Perorangan di Sekitarnya. Varia Justicia , 12 (1), pp: 63 - 86.

13. Jhingan, M.L. 2014. Ekonomi Pembangunan dan Perencanaan. Raja Grafindo Persada: Jakarta.

14. Jumaidi, Lalu Takdir, Jalaludin \& Ahyar, Muhamad. 2019. Eksistensi Minimarket terhadap Kelangsungan Usaha Toko Kelontong dan Waserda. Jurnal Magister Manajemen Universitas Mataram, 8 (2), pp: $186-202$.

15. Kumar, P. Kishore, Kumar, N. Ramesh \& Naveen, Ch.. 2016. A Study on Consumers Motivating Factors in Shopping at Organized Retail Outlets. Saudi Journal of Business and Management Studies, 1 (3), pp: 149 - 153.

16. Leonnard. 2017. Measuring Grocery Stores Service Quality in Indonesia: a Retail Service Quality Scale Approach. Studies and Scientific Research, Economics Edition, 26, pp: 32 -44 .

17. Listihana, Wita Dwika, \& Aquino, Afvan da Arizal. 2014. Dampak Keberadaan Minimarket terhadap Modal Kerja dan Pendapatan Warung Tradisional di Kecamatan Rumbai dan Rumbai Pesisir Kota Pekanbaru. Jurnal IImiah Ekonomi dan Bisnis, 11 (1), pp: 553 - 562. 
18. Makhitha, Khathutshelo M, \& Nonkululeko, M. Khumalo. 2019. The Influence of Supermarket Attributes on Consumer Selection of a Supermarket: a South African Perpective. Journal of Consumer Sciences, 47, pp: $14-27$.

19. Mankiw, N. Gregory, Quah, Euston \& Wilson, Peter. 2014. Pengantar Mikro Ekonomi. Salemba Empat: Jakarta.

20. Martin, Iqbal. 2017. Penerapan Kebijakan Zonasi dalam Penataan Pasar Tradisional dan Pasar Modern Kota Bandung (Suatu Tinjauan Yuridis dari Perspektif Otonomi Daerah). Jurnal Wawasan Yuridika, 01 (02) pp: 107 - 138.

21. Mas, Nasharuddin, Thoyib, Armanu, Surachman \& Solimun. 2014. Trader Sturdiness at Traditional Market in Facing Modern Market Progress. International Journal of Business and Management Invention, 3(5), pp: $49-58$.

22. Masyhuri, Mahmudah \& Utomo, Supri Wahyudi. 2017. Analisis Dampak Keberadaan Pasar Modern terhadap Pasar Tradisional Sleko di Kota Madiun. Jurnal Akuntansi dan Pendidikan, 06 (01), pp: $59-72$.

23. Muhzinat, Zumrotul \& Achiria, Siti. 2019. Dampak Keberadaan Minimarket terhadap Toko Kelontong di Pasar Klampis Kabupaten Bangkalan Madura. Jurnal Ekonomi dan Perbankan Syariah, 6 (2), pp: $203-211$.

24. Nelwan, Jovan Wiradhana, Lapian, S.L.H.V. Joyce \& Rumokoy, Farlane S., 2017. The Existence of Traditional Market Toward Modern Market in Tomohon City. Jurnal EMBA, 5 (3), pp: $3348-3355$.

25. Nesset, Erik, Bergem, Ola, Nervik, Bjorn, Sorlie, Even Schioll \& Helgesen, Oyvind. 2021. Building Chain Loyalty in Grocery Retailing by Means of Loyalty Programs - A Study of the Norwegian Case. Journal of Retailing and Consumer Services, 60, pp: $1-13$.

26. Nicholson, Walter. 2002. Mikroekonomi Intermediate dan Aplikasinya. Erlangga: Jakarta.

27. Nuraini, Ani dan Khairunnisa. 2018. Pengaruh Faktor Eksternal dan Internal Pedagang Terhadap Ketahanan Pedagang Warung Tradisional dalam Menghadapi Pesaing Minimarket. Seminar Nasional dan Call for Paper Manajerial dan Kewirausahaan, Jakarta 25 Agustus 2018.

28. Otaibi, Naif Mutlaq Al \& Kausar, Yasmeen. 2014. An Overview of Consumer Loyalty, Perceived Service Quality and Customer Satisfaction: Brief on Saudi Grocery Stores. Journal of Entrepreneurship and Business Innovation, 1 (1), pp: $79-122$.

29. Peraturan Presiden Republik Indonesia Nomor 112 tahun 2007.

30. Pertiwi, Marina Intan, yulianto, Edy, dan Sunarti. 2016. Pengaruh Bauran Pemasaran Terhadap Keputusan Pembelian. Jurnal Administrasi Bisnis, 37 (1), pp: 179 - 186.

31. Saber, Marcus dan Weber, Anja. 2019. Sustainable Grocery Retailing: Myth or Reality? A Content Analysis. Business and Society Review, 124, pp: 479 - 496.

32. Saha, Sunetra, Sharma, Ashok \& Kumar, Anita. 2019. Factors that Influence Retail Store Preference and Impact of in-Store Digitization. International Journal of Recent Technology and Engineering, 8 (4), pp: 8715 - 8722.

33. Supriyanto, Muhammad dan Taali, Muhammad. 2018. Pengaruh bauran Pemasaran (Marketing Mix) Terhadap Pengambilan Keputusan Menginap di The Sun Hotel Madiun. Epicherisi, 2 (1), pp: $13-21$.

34. Utami, Hesty Nurul dan Firdaus, lqbal Fauzi Akbar. 2018. Pengaruh Bauran Pemasaran Terhadap Perilaku Online Shopping: Perspektif Pemasaran Agribisnis. Jurnal Ecodemica, 2 (1), pp: $136-146$.

35. Vanessa, Nesya dan Japutra, Arnold. 2017. Contextual Marketing Based on Customer Buying Pattern in Grocery E-Commerce: The Case of Bigbasket.com (India). Asean Marketing Journal, 9 (1), pp: $56-67$.

36. Wieland, Thomas. 2018. Competitive Locations of Grocery Stores in The Local Supply Context- The Case of The Urban District Freiburg-Haslach. European Journal of Geography, 9 (3), pp: $98-115$.

37. Wijayati, Putri Agus. 2013. Model Pemberdayaan Pasar Tradisional Berbasis Ekonomi Kerakyatan di Kota Semarang. Paramita, 23 (2), pp: 167 - 178. 
38. Windayani, I A. Ratih Sasmitha dan Marhaeni, A.A.I.N. 2019 The Effect of Tourism Village Development on Community Empowerment and Welfare in Tourism Village of Panglipuran, Bangli District of Indonesia. RJOAS, 10 (94), pp: 257 - 265.

39. Wiputra, Panca, Sumarwan, Ujang dan Wijayanto, Hari. 2015. Model Pelayanan Pelanggan pada Toko Eceran Tradisional. Jurnal Manajemen IKM, 10 (2) pp: $194-210$.

40. Yanti, Vera Agustina, Amanah, Siti, Muldjono, Pudji dan Asngari, Pang. 2018. Faktor yang Mempengaruhi Keberlanjutan Usaha Mikro Kecil Menengah di Bandung dan Bogor. Jurnal Pengkajiandan Pengembangan Teknologi Pertanian, 20 (2), pp: 137 - 148.

41. Yulita, Farisa Harahap, Simanjuntak, Megawati \& Sartono, Bagus. 2019. Shopping Behavior of Indonesian Customer in Modern Retail. RJOAS, 4 (88), pp: 95 - 101.

42. Yuningrum, Heny. 2016. Usaha untuk Meningkatkan Loyalitas Toko Kelontong dalam Menghadapi Usaha Ritel yang Menjamur di Masyarakat. Jurnal Economica, 7 (2), pp: $109-139$. 